\title{
Hydrothermal effect on groundwater level fluctuations: case studies of Čepkeliai and Rèkyva peatbogs, Lithuania
}

\author{
Justas Kažys ${ }^{1}$, \\ Egidijus Rimkus ${ }^{1}$, \\ Julius Taminskas ${ }^{2}$, \\ Sigita Butkutè ${ }^{1}$ \\ ${ }^{1}$ Vilnius University, \\ M. K. Čiurlionio St. 21, \\ LT-03101 Vilnius \\ E-mail: justas.kazys@gf.vu.lt; \\ egidijus.rimkus@gf.vu.lt; \\ ${ }^{2}$ Nature Research Centre, \\ Akademijos St. 2, \\ LT-08412 Vilnius \\ E-mail julius.taminskas@geo.lt
}

\begin{abstract}
Kažys J., Rimkus E., Taminskas J., Butkutè S. Hydrothermal effect on groundwater level fluctuations: case studies of Čepkeliai and Rèkyva peatbogs, Lithuania. Geologija. Geografija. 2015. T. 1(3). ISSN 2351-7549.

The peatbogs are very unique and relatively vulnerable ecosystems for every kind of disturbances. This research analyses the relationships between groundwater level (GWL) fluctuations and meteorological conditions in Lithuanian peatbogs. Two case study areas (Čepkeliai and Rèkyva peatbogs) with permanent GWL monitoring points were investigated. The period from 2002 till 2011 was analysed in Čepkeliai and the period from 2011 till 2014 in Rèkyva. The final results indicate that rainfall is the most important factor determining the groundwater level fluctuations in the warm season, while temperature and evapotranspiration play only a minor role. The relationship between GWL and precipitation strongly depends on soil properties. The findings in Rekyva revealed that the reactions of GWL on meteorological conditions in various parts of the peatbogs were not the same. Also, the analysis showed that the reaction of GWL on precipitation differs in cold and warm seasons.
\end{abstract}

Key words: groundwater level, Lithuanian peatbogs, Čepkeliai, Rèkyva, precipitation, CLIMPEAT project

\section{INTRODUCTION}

Peatlands are a very important part of hydrological (storing organic materials and trapping pollutants, attenuating flood peaks and storm flows) and climatological (reducing the amount of greenhouse gases in the atmosphere, processing of carbon sequestration) cycles. Peatland ecosystems are characterized as unique biodiversity habitats: a natural home for variety of mosses, carnivorous plants, shrubs, etc.; nesting areas and hunting grounds for several species of mammals, birds and insects.

The peatlands are globally important terrestrial carbon stocks covering approximately $15 \%$ of the boreal and subarctic regions (MacDonald et al., 2006; BACC, 2008). The Baltic Sea Region with its extensive substantial wetland areas plays a significant role in the carbon storage in vegetation and soils (BACC, 2015). In Lithuania more than 25\% of the territory is covered by wetlands of which
$7.8 \%$ has developed into peatbogs (Povilaitis et al., 2011). According to the Ramsar classification non-forested and forested peatlands cover even more $-9.9 \%$ area of Lithuania (Taminskas et al., 2012).

Globally wetlands are indicators and regulators of climate change processes (Kirpotin et al., 2009; Mitsch, Hernandez, 2013). The peatlands are recognized to have the characteristics of self-regulating systems, and the extent of regulation is a function of the peatland type and the source of water and nutrients (Frolking et al., 2009). However, climatic and anthropogenic effects on hydrological cycles in peatlands are evident (Auterives et al., 2011). In the past, hydrological self-regulating processes have been studied in Lithuanian peatland ecosystems. Researches of different extents and purposes were provided in Rèkyva (Gaigalas et al., 2008; Linkevičienè et al., 2008; Šimauskienè et al., 2008); in Čepkeliai (Kibirkštis, 2002; Taminskas et al., 
2008; Mažeika et al., 2009); in Aukštumala (Pakalnis et al., 2008; Jarašius et al., 2014); and in Kamanos (Ruseckas, Grigaliūnas, 2008) peatbogs.

Groundwater level (GWL) fluctuations in peatbogs study presented in this article are a part of "Climate Change in Peatlands: Holocene Record, Recent Trends and Related Impacts on Biodiversity and Sequestered Carbon (CLIMPEAT)" project (www.climpeat.lt). It is a result of the Lithuania-Swiss cooperation programme run by the Nature Research Centre (the Leading Partner), the University of Bern, the Institute for Geological Sciences and Vilnius University and analysing different peatbogs distributed in Lithuania. The project explores the interconnections and interdependencies of peatlands ecosystems with climate (change), anthropogenic activity and sequestered carbon. Tree growth in the peatlands is mainly affected by groundwater fluctuations, with a high water table resulting in lower oxygen uptake and more limited nutrient assimilation by the root system. As a consequence, woody vegetation dynamics in peatlands has been shown to be an integrator of past water table fluctuations. Some scientific results of the CLIMPEAT project are already published (Edvardsson et al., 2015a; 2015b).

Čepkeliai $\left(5.858 \mathrm{~km}^{2}\right)$ and Rèkyva $\left(2.608 \mathrm{~km}^{2}\right)$ are complex wetland systems with dominant peat- bog areas, 82 and 68\%, respectively (Mierauskas et al., 2005; Povilaitis et al., 2011). This article concentrates only on recent GWL fluctuations in these peatbogs. The main goal of the research was to find differences and similarities of GWL reactions to hydrothermal characteristics on various timescales (monthly and daily means, longlasting rains and dry periods). The importance of the soil type (in Čepkeliai) and the lake influence (in Rèkyva) on GWL fluctuations were explored. The determined relations could help making GWL projections to past (Holocenne) and future (up to 2100). Also it will contribute to the conservation and sustainable management of the peatlands through a better appraisal of impacts, and/or feedback loops between pedospheric, atmospheric, and anthropogenic activities.

\section{DATA AND METHODS}

GWL fluctuations and meteorological conditions were analysed in Čepkeliai and Rèkyva peatbogs. The monitoring periods of GWL in Čepkeliai and Rèkyva peatbogs are different (Table): in Čepkeliai it covers from 7 to 10 years (depending on the borehole) and 4 years of monitoring for all boreholes in Rekyva. Also the number of boreholes, soil horizons and measuring frequency were different in both peatbogs (Table).

Table. Borehole characteristics in Čepkeliai and Rèkyva peatbog monitoring sites

\begin{tabular}{|c|c|c|c|c|}
\hline \multicolumn{2}{|c|}{ Boreholes } & \multirow{2}{*}{ Horizons } & \multirow{2}{*}{ Peat layer thickness, m } & \multirow{2}{*}{ Operating time } \\
\hline No. & Altitude & & & \\
\hline \multicolumn{5}{|c|}{ Čepkeliai } \\
\hline $1-\mathrm{G}(29284)$ & 134.81 & Sand & - & $2002-2008$ \\
\hline $2-\mathrm{G}(29289)$ & 133.70 & Sand under peat & 3.5 & 2002-2009 \\
\hline 3-G (29289-5) & 137.79 & Sand & - & $2007-2011$ \\
\hline 4-G (29289-4) & 136.21 & Sand & - & $2002-2011$ \\
\hline 1-A (29285) & 132.69 & Peat & 1.3 & $2002-2008$ \\
\hline 2-A (29287) & 132.98 & Peat & 1.8 & $2002-2008$ \\
\hline 3-A (29288) & 133.50 & Peat & 3.5 & $2002-2011$ \\
\hline 4-A (29289-3) & 133.29 & Peat & 1.5 & $2002-2011$ \\
\hline 5-A (29289-2) & 133.60 & Peat & 3.2 & $2002-2011$ \\
\hline 6-A (29289-1) & 133.69 & Peat & 5.1 & $2002-2011$ \\
\hline \multicolumn{5}{|c|}{ Rèkyva } \\
\hline $1(25659)$ & 131.08 & Peat & Unknown & 2011-2014 \\
\hline $2(25658)$ & 133.28 & Peat & Unknown & 2011-2014 \\
\hline $3(25657)$ & 133.99 & Peat & Unknown & 2011-2014 \\
\hline $4(25655)$ & 134.14 & Peat & Unknown & $2011-2014$ \\
\hline $5(25654)$ & 133.25 & Peat & Unknown & 2011-2014 \\
\hline $6(25653)$ & 132.79 & Peat & Unknown & 2011-2014 \\
\hline
\end{tabular}


In the Čepkeliai peatbog measurements were carried out in 10 boreholes (Fig. 1) during the warm season of the year (from 10 April to 20 October) at the last day of each ten-day period (e. g. 10th, 20th and 30th day of month). Measurement results are presented as the absolute GWL height (m). All boreholes were divided into three groups: boreholes in the sand (1-G, 2-G, 3-G, 4-G), boreholes in a thin layer of peat (1-A, 2-A, 4-A) and boreholes in a thick layer of peat (3-A, 5-A, 6-A). Because the GWL in separate groups varies synchronously (statistically significant correlation coefficients exceeded 0.8 ), the average values of each group GWL were estimated in order to simplify the study. It is necessary to mention that the averaging was made only after filling data gaps. This was done using a difference method with supplementary data from other boreholes which belong to the same group. Also, additional data of daily precipitation and air temperature in 2002-2011 from the Varena Meteorological Station were used.

In the Rekyva peatbog monitoring sites are equipped will fully automated GWL and temperature meters (measuring interval is 1 hour). The GWL data cover a period from 1 March 2011 to 31 December 2014 (Taminskas et al., 2015). The GWL is measured in 6 boreholes: the 1st borehole is located closest to Rekyva Lake and the 6th one is the most far from the lake near an active peat quarry (Fig. 2). The measurement results are presented as the absolute GWL height $(\mathrm{m})$. Automatic measurements of GWL were carried out every day, while small data gaps were eliminated using innterpolation method. Only two periods were excluded from the analysis because of larger data gaps: from 25 January to 18 April 2013 in the 3rd borehole; and from 24 November to 31 December 2013 in the 4th borehole. Also, additional data were used (Taminskas et al., 2015):

- Daily water levels of Rèkyva Lake with 130.77 m absolute height spillway;

- The daily precipitation amount and air temperature from the Rèkyva Automatic Meteorological Station and the Šiauliai Meteorological Station.

For possible comparison of the results between Čepkeliai and Rèkyva peatbogs daily GWL data in Rekyva was adjusted for the same measuring period as it was used in Čepkeliai, i. e. 1 measurement in 10 days for the warm season (from 10 April to

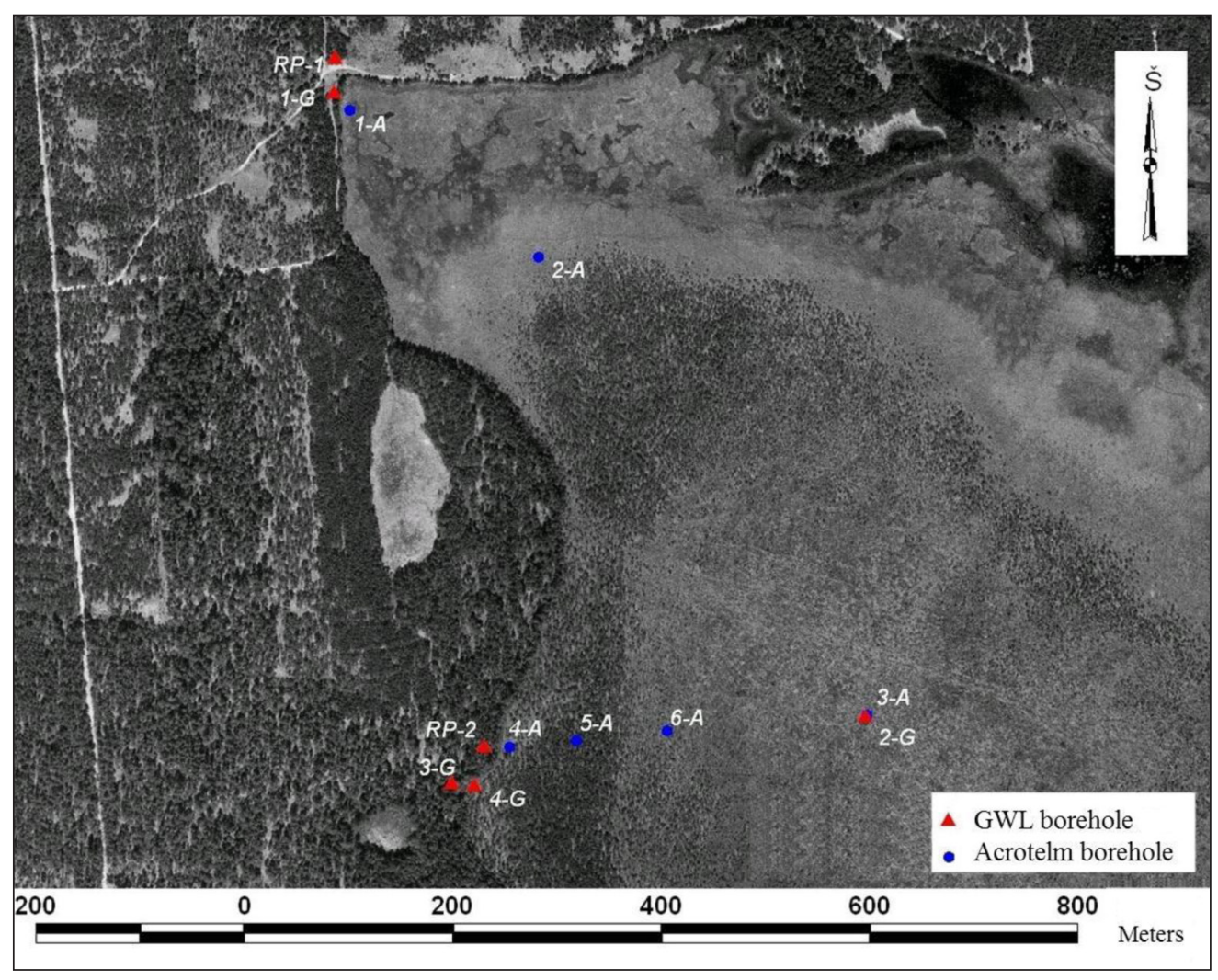

Fig. 1. Distribution of GWL monitoring boreholes in the Čepkeliai peatbog (under Kibirkštis, 2007) 


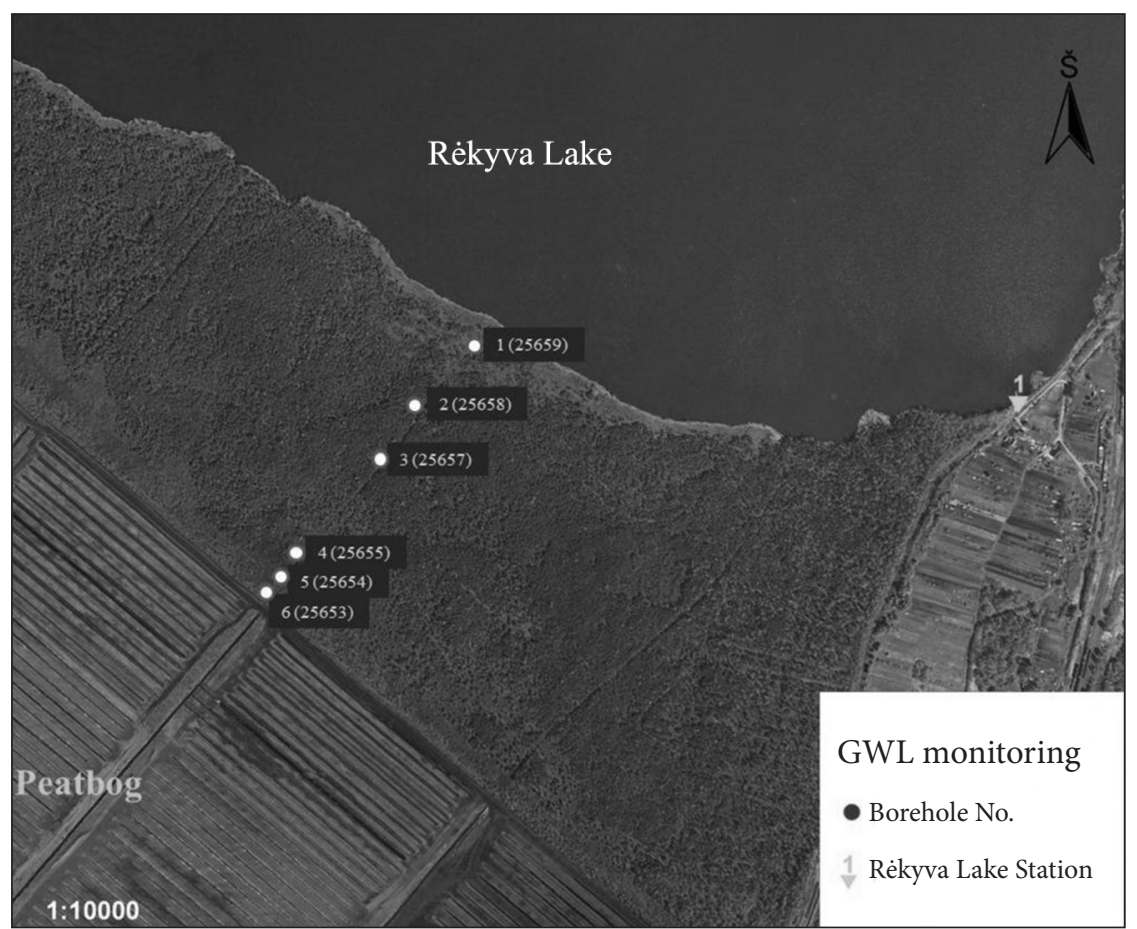

Fig. 2. Distribution of GWL monitoring boreholes in the Rèkyva peatbog and Rèkyva Lake Station (triangle) (under Taminskas et al., 2015)

20 October). The following GWL characteristics were used in the study:

- The GWL value before the warm season. For this purpose the data from 30 April were used. Annual monitoring starts at 10 April, but we tried completely to eliminate the possible effect of the late snow melt on following GWL fluctuations.

- The GWL value at the end of the warm season (20 October). Coincides with the last measurement date at the monitoring sites.

- The groundwater level change during the warm season. Calculated as the GWL difference between 20 October and 10 April of the same year.

- The groundwater level change within a 10-day period. Calculated as the difference between two consecutive measurements minus the mean warm season trend value. Integrated values of GWL changes were calculated for each ten-day period. It was obtained as a sum of ten-day GWL changes in a particular season up to a certain date (from 30 April).

The mean values of the three borehole groups (sand, thin and thick peat layers) in Čepkeliai and the mean values of Rekyva peatbog boreholes were compared with meteorological parameters. The relationships were considered when a statistical significance was $\mathrm{p}<0.05$. The following meteorological characteristics were used in the study:
- The precipitation amount that fell during the cold period and the mean air temperature of the same period (from 20 October to 30 April);

- The precipitation amount that fell during the warm period and the average temperature of the same period (from 30 April to 20 October);

- The annual precipitation amount and the mean annual temperature (estimated for the period from 30 April to 30 April and from 20 October to 20 October);

- The precipitation amount that fell during ten days between the two measurements at the GWL monitoring points and the average temperature of the same period. Anomalies of these values (i. e. difference between the measured values and mean values of the same ten-day period in 1981-2010) were also calculated;

- Integrated values of anomalies of meteorological characteristics were calculated for each tenday period. It was obtained as a sum of ten-days anomalies in a particular season up to a certain date (from 30 April);

- The potential evapotranspiration (PET) according to the Thornthwaite equation (Thornthwaite, Mather, 1957): PET values were calculated for each month for the period from May till September; 
- The hydrothermal coefficient (HTC) (Selianinov, 1928) was calculated for the whole warm season as well as for every 30 days period. The first HTCs were obtained for 30 May (after 30 consecutive days).

Automated hourly data from Rèkyva allow making a more detailed analysis of GWL fluctuations. Specific research was made only in the Rèkyva peatbog during the 2011-2014 period. First, GWL values and GWL amplitudes annual cycle relations with the precipitation amount were calculated. Then monthly maximums, averages, minimums of GWL were analysed in separate boreholes and combinations of all (1-6 boreholes), the nearest (1-3) and farthest (5-6) to the lake boreholes for finding a possible Rèkyva Lake effect on GWL fluctuations.

Also the influence of wet (lasting rains) and dry periods on daily GWL fluctuations was analysed in the Rekyva peatbog in the 2011-2014 period. The analysis of the following cases was done:

- The cases of cumulative GWL change sums for $1,3,5$, and 7 consecutive days. Two standard deviations $(2 \sigma)$ level used to find the largest GWL changes. The $2 \sigma$ level was exceeded 44 times for the one day (GWL-1) cumulative change sum, 41 times for GWL-3, 46 times for GWL-5, and 44 times for GWL-7. The cold season and duplicate cases were excluded and the final analysis was made using 23 (GWL-1), 12 (GWL-3), 10 (GWL5), and 10 (GWL-7) cases.
- The longest precipitation period (September 2013) case study.

- The cases without precipitation throughout ten consecutive days for the representation of the influence of dry periods on GWL.

\section{RESULTS}

\section{Precipitation influence on GWL}

It was found that on the average the GWL decreases during the summer in all groups of boreholes (Fig. 3). The same effect was found by Ruseckas and Grigaliūnas (2008) in the Kamanos peatbog. The largest average decrease was observed in the sand $(27 \mathrm{~cm})$, while the smallest one in the thick layer of peat $(8 \mathrm{~cm})$. The unique decrease ratios of different soils clearly illustrate that the impact of rainfall anomalies on GWL fluctuations is uneven. In the Rekyva peatbog, where peat thickness is unknown, an average decrease reached $10 \mathrm{~cm}$.

Precipitation is the most important factor in determining GWL fluctuations during the warm season as well as determining the annual changes. The research in the Čepkeliai peatbog revealed that the strength of correlation depends on the type of soil. In almost all cases the correlation between rainfall and the GWL is the strongest in the sand, while in the thick layer of peat such relation is weaker. This can be attributed to the fluctuation range of GWL. Statistically significant correlations between the annual precipitation amount and the annual

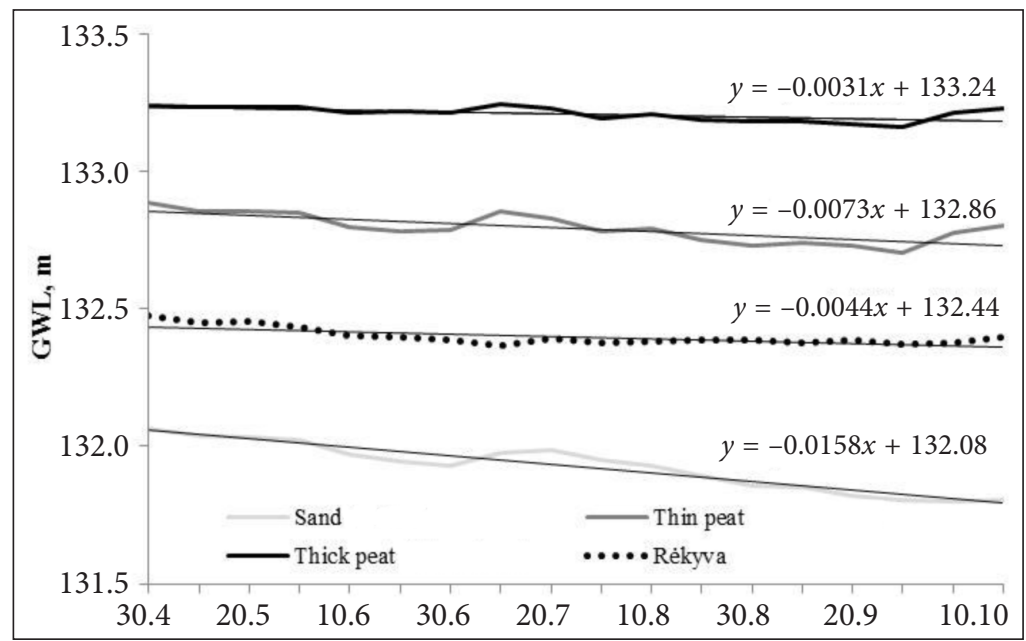

Fig. 3. Mean seasonal fluctuations of GWL (with linear trends) during 30 April and 20 October in different soil types in the Čepkeliai peatbog according to the data from 2002-2011 and in the Rekyva peatbog (dotted line) according to the data from 2011-2014 
GWL changes in the sand and the thin layer of peat (Fig. 4a), and between the warm period precipitation amount and GWL changes in the same soils (Fig. 4b) were found.

The largest positive annual GWL anomaly in Čepkeliai was recorded in 2010 when the precipitation amount in Varena MS was the highest since 1951. A very similar GWL anomaly was observed in 2005. The same sign of changes in GWL was also determined in 2007, although the precipitation amount was relatively low. This can be explained by the fact that during the first ten-day period of July 2007 the precipitation amount reached $114.2 \mathrm{~mm}$ and it led to a sharp and strong growth of GWL (from $0.23 \mathrm{~cm}$ in the thick peat to 0.54 in the sand). Such quick soil saturation could determine that despite the following negative rainfall anomalies the GWL annual balance remained positive. It is necessary to mention that in the first ten-day period of August 2005 the precipitation amount was even higher $(193.6 \mathrm{~mm}$ ) but the GWL growth was lower $(23-39 \mathrm{~cm})$. It can be partly explained by the fact that almost half of the observed total amount of precipitation fell on 10 August and there is not any information about the GWL observation time. It is possible that GWL was measured before the start of extreme rain. Moreover, GWL grew during the next ten-day period, although significant negative precipitation anomaly was recorded. On the other hand, there are several cases when after heavy precipitation events GWL remained unchanged or even decreased. This can be attributed to the unevenness of the summer precipitation field.
A statistically significant negative correlation between the annual precipitation amount and the annual GWL changes and between the warm period precipitation amount and GWL changes was found in the Rèkyva peatbog. Even though in 2012 the annual precipitation amount exceeded the 1981-2010 average by $35 \%$, the GWL decreased most $(12 \mathrm{~cm})$. It could be explained by several reasons. First, only 4 years (2011-2014) of Rèkyva peatbog data are not enough to get reliable correlation coefficients. Another reason is that the correlation between the precipitation and GWL in the thick peat layer (according to findings in the Čepkeliai peatbog) is not strong. Edvardson et al. (2015a) found that GWL changes were more determined by long-term precipitation cycles than the anomalies of the same year. Only generalized information on the GWL and precipitation regime could be presented. The GWL is the highest at the end of the cold season when snow is starting to melt. The lowest values were recorded in February and March 2014, the highest ones in March and April 2011 and 2012 as a result of snow melting in the peatbog territory (Fig. 5). Also high GWL could stay during spring and autumn if meteorological conditions are moist and cool. Meanwhile, the GWL tends to decrease during the analysed period (1 March 2011 - 31 December 2014). The same tendencies were observed in other researches (Auterives et al., 2011; Kettridge, Waddington, 2014).

It was found that the relationship between the ten-day rainfall anomalies and GWL changes is statistically significant (Fig. 6) and varies from 0.59 (Fig. 6a) in the sand to 0.71 (Fig. 6c) in

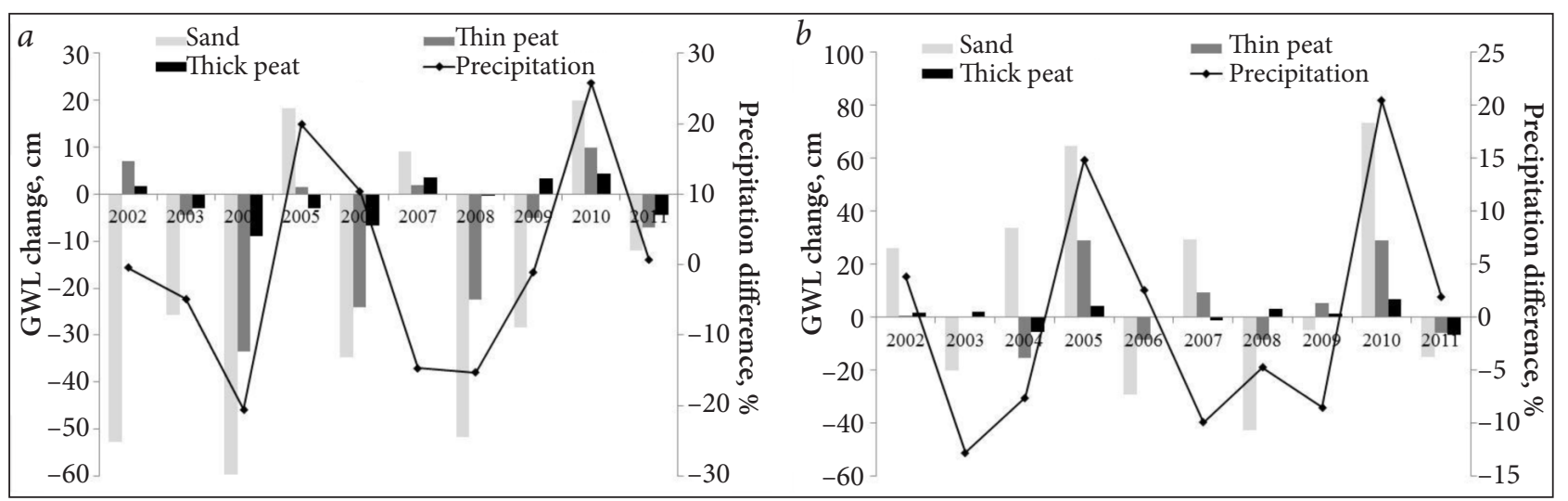

Fig. 4. Annual GWL changes in different soil types and the deviation of the precipitation amount from long-term mean values (\%) estimated in the Čepkeliai peatbog: the period from 20 October to 20 October $(a)$ and the warm period from 30 April to 20 October $(b)$ 


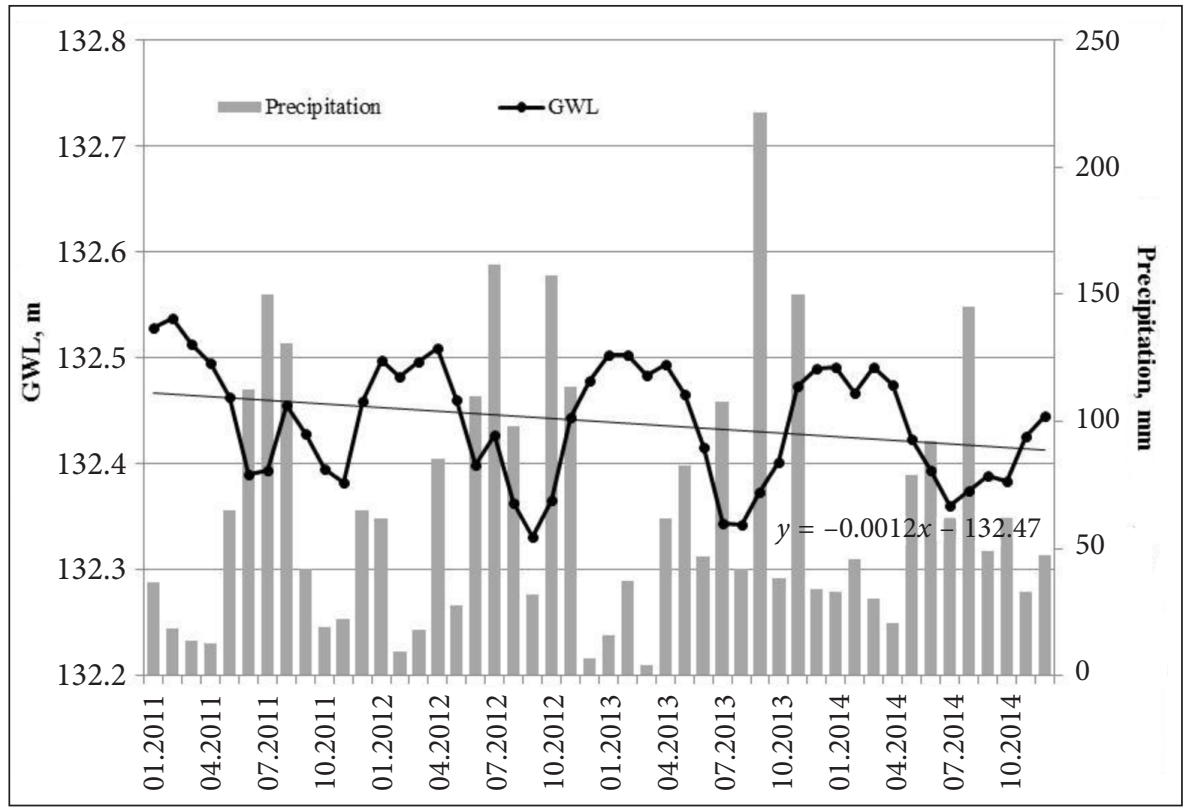

Fig. 5. Dynamic of the mean groundwater level and monthly sums of precipitation (with trendline and equation) in Rèkyva in 2011-2014

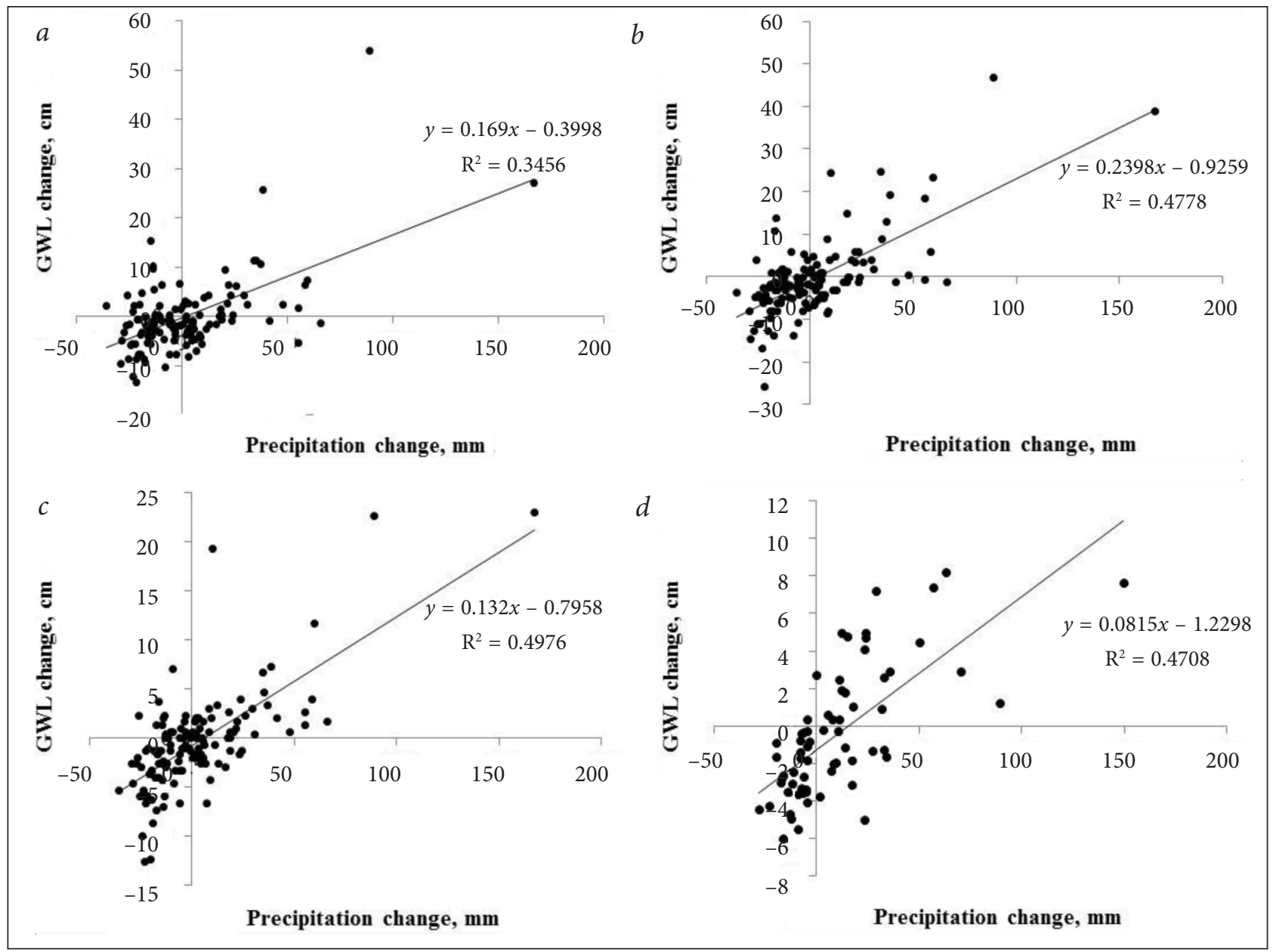

Fig. 6. Relationship between ten-day anomalies of the warm period (May-October) precipitation amount (mm) and GWL changes $(\mathrm{cm})$ in the Čepkeliai peatbog in: sand $(a)$; thin peat $(b)$; thick peat $(c)$; and in the Rèkyva peatbog $(d)$ 
the thick layer of peat, what shows that the peat soils are more sensitive to short-term precipitation anomalies. Also the same sensitivity to short-term anomalies was found in Rèkyva peat soils (Fig. 6d).

\section{GWL relation with PET and HTC}

If precipitation has a positive effect on GWL change, i. e. more precipitation increases GWL, then air temperature and PET should have an opposite effect on a warm season, i. e. higher air temperature and PET values should lead to lower GWL values. Statistically significant relationships have not been determined during the analysis of air temperature and potential evapotranspiration (PET) influence on GWL in the Čepkeliai peatbog. During the cold period of the year a correlation sign is positive, because more precipitation falls during the warm winters, while a relation sign is not so clear in the summer. No statistically significant correlation was found for both seasons in the Rekyva peatbog, possible reasons already explained in the subchapter above. However, a weak negative relation between PET values and GWL change existed in the warm season in Rèkyva.

The correlation between ten-days GWL changes in the warm season and air temperature anomalies is negative, but in case of longer periods, this relationship is usually positive. The relationship between ten-day air temperature and precipitation anomalies during the warm period also has a negative sign (statistically significant weak correlation coefficient equals -0.24 ), while a record high amount of precipitation may fall both in warm (2010) and relatively cool summers (2005).
In both peatbogs, in most years a very high correlation was observed between the GWL fluctuations and HTC values, which combines air temperature and precipitation and describes the hydrothermal conditions of the warm season. The correlation coefficient between the GWL changes during the whole warm season and the HTC values reaches 0.72 in the sand. A statistically significant correlation was also recorded in the thin layer of peat. In some years the 30day HTC index and the GWL change values of the same period are very closely linked. The correlation coefficient in individual years can exceed 0.95 (Fig. 7a) and 0.90 (Fig. 7b).

\section{Rèkyva Lake influence on GWL}

The usage of daily GWL data allowed reconstructing the annual cycle in Rèkyva, while in Čepkeliai data were collected once in 10 days and only for the warm season (April-October). Annual fluctuations of GWL relative values (Fig. 8a) and its amplitudes (Fig. 8b) relations with precipitation amounts were calculated. The annual cycle revealed that GWL reaches the highest values in the end of April and the lowest ones in the middle of September. According to the precipitation and GWL fluctuations (Fig. 8) three seasons could be distinguished: cold (December-April), warm (June-October), and intermediate (May and November).

Because seasonal fluctuations are typical for the GWLs (Fig. 8), correlations between all 6 boreholes were calculated in three seasons: cold (December-April), warm (June-October), and intermediate (May and November). For the evaluation

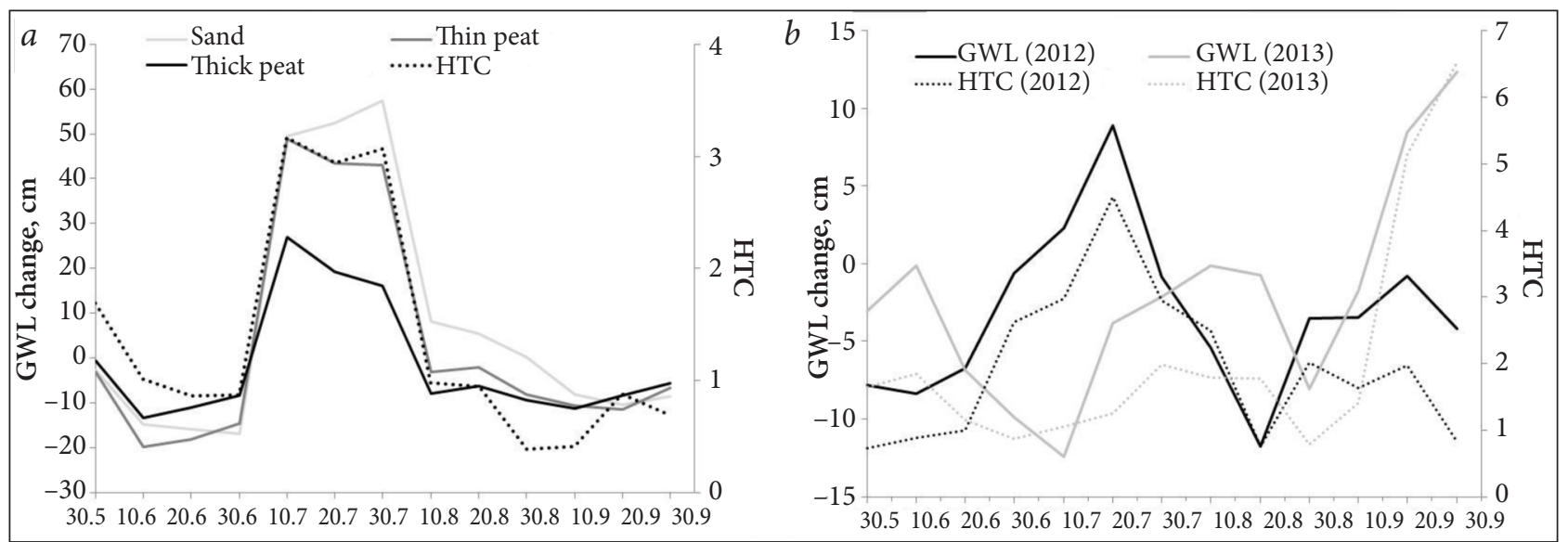

Fig. 7. Dynamic of 30-day GWL changes and HTC values in the Čepkeliai peatbog in 2007 (a); in the Rekkyva peatbog in 2012 and $2013($ b) 


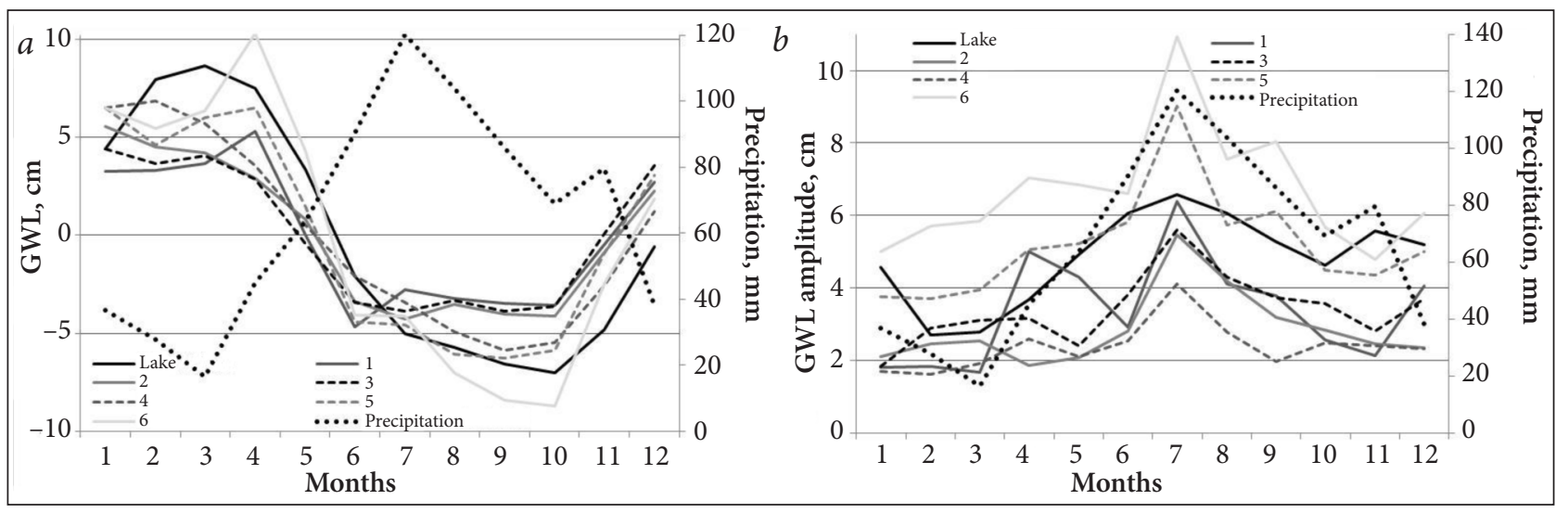

Fig. 8. Averaged maximum values $(a)$, amplitudes $(b)$ of Rèkyva Lake and 6 groundwater boreholes levels $(\mathrm{cm})$ and precipitation sums $(\mathrm{mm})$ throughout the year in 2011-2014

of fluctuation differences between six boreholes monthly GWL maximums, averages, minimums and its amplitudes were analysed (Fig. 9). The first 2 boreholes are closest to Rekyva Lake; the 3rd and the 4 th ones are situated on a watershed, the last 2 boreholes are closest to the peat excavation part of the peatbog (Fig. 3).

The evaluation of the correlation between the daily GWL values of Rèkyva Lake and peatbog boreholes proved that all coefficients are statistically significant $(\alpha=0.05)$, except the correlation between the lake and the 3rd borehole in cold and warm periods. A possible reason is that the 3rd borehole is characterized by the highest absolute GWL values (Fig. 9). Normally, correlations between the closest points are highest. In all periods, the highest values (0.89-0.95) are between the farthest boreholes from the lake (5th and 6th).

The reactions of GWL fluctuations on environment conditions are uneven in separate parts of the Rèkyva peatbog. They depend on the distance from the lake, absolute altitudes, thickness of the peat layer, plant type, and even from the season of the year. The fluctuations of GWL maximum (Fig. 10a) and minimum (Fig. 10b) values in the peatbog are different compared to Rèkyva Lake's water levels. The GWL maximums are closely related to the extra water inflow, i. e. precipitation, snow and ice regime (Fig. 10a). In the warm period, excess water could be stored in thicker layers

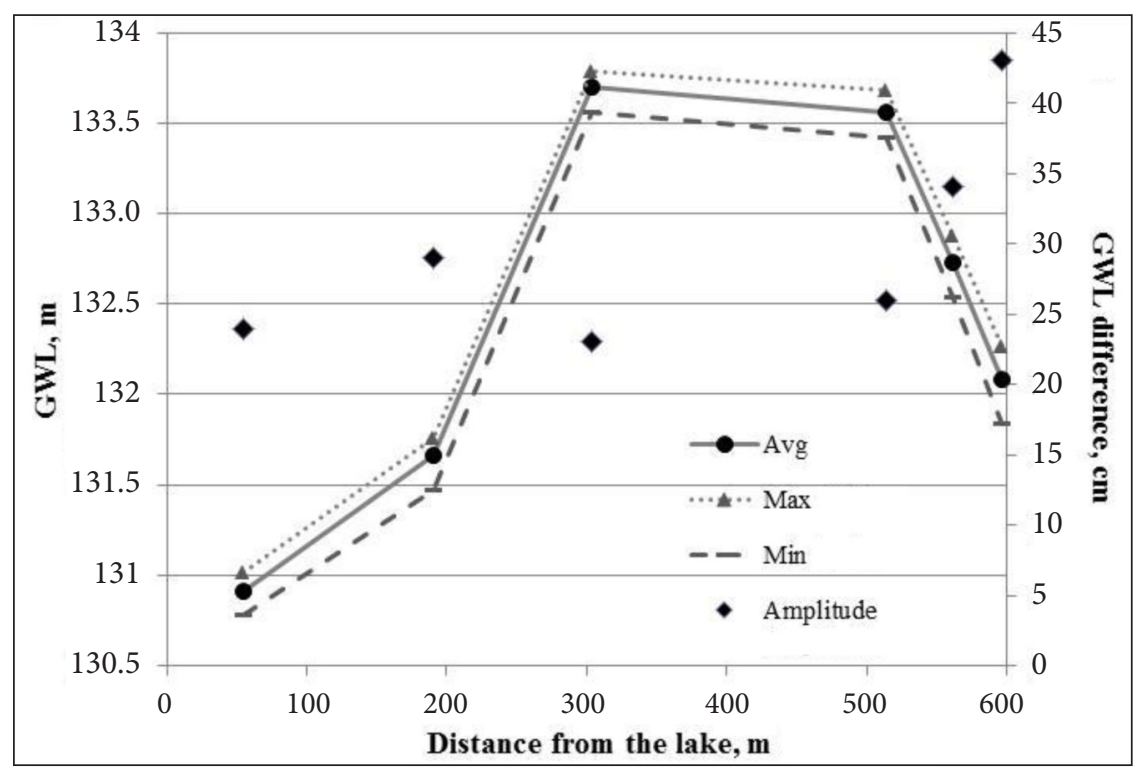

Fig. 9. GWL characteristics for different boreholes in the Rekyva peatbog in 2011-2014 

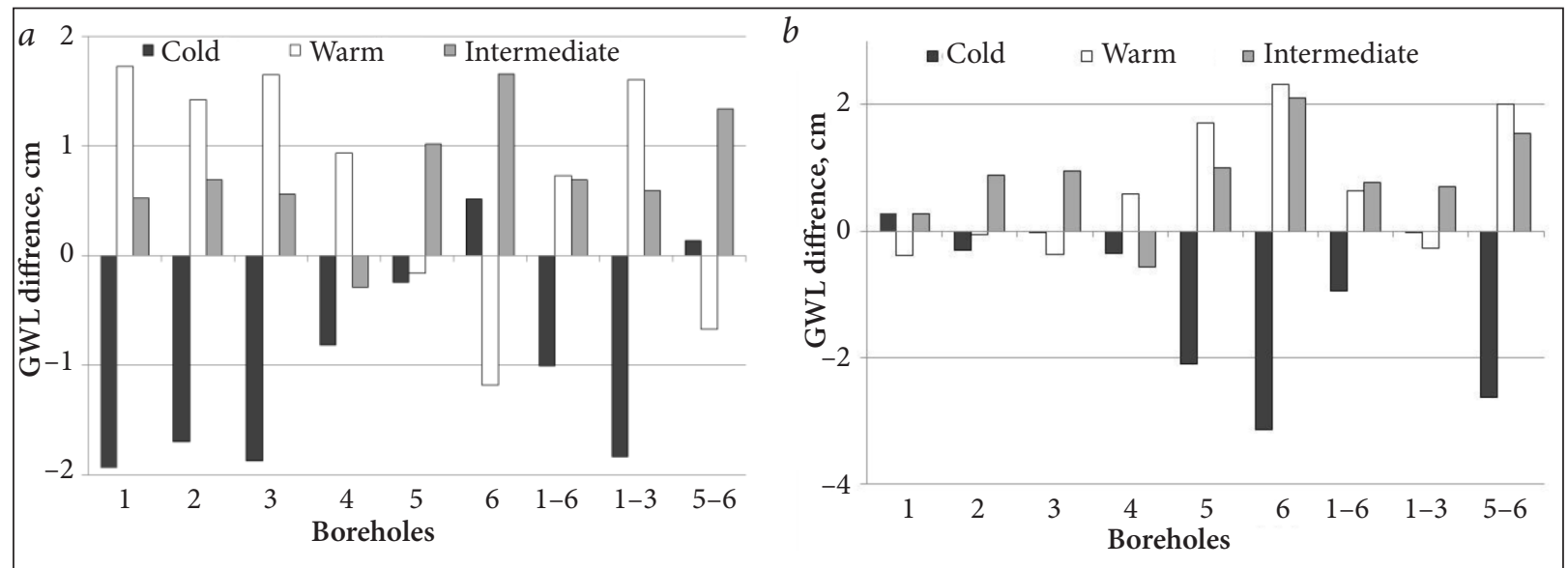

Fig. 10. Differences of GWL maximum (a) and minimum (b) values during cold, warm and intermediate seasons in Rèkyva Lake and the peatbog (different combinations of boreholes) in 2011-2014

of the peat, therefore GWL in the 5th and 6th boreholes are lower than in the lake. Closer to the lake more effect of heavy rain is felt. An opposite effect could be seen in the cold season: lower GWL values closer to the lake. Thinner layers of peats are faster in freezing and in snow covering. Water does not reach the GWL and stays on the surface. Thicker layers are slower in freezing; excess water could move into the peat and elevate GWL slightly. Maximums of GWLs are characterized in large margins of different sign compared to the lake level.

GWL minimum values are associated with water shortage, i. e. dry and hot conditions in warm periods and dry conditions in cold periods (Fig. 10b). Because of more regulatory abilities in thicker peat layers, the 5th and 6th boreholes have higher minimum GWL in warm and intermediate periods. Differences of the minimum GWL between the lake and closest boreholes (1-3) almost disappear, i. e. fluctuations of GWL are very similar in the lake and the boreholes.

\section{GWL reaction to wet and dry periods}

The correlation of cumulative precipitation sums from 1 to 7 days with cumulative GWL change sums are showed in Fig. 11. The correlation coefficients stayed almost stable (0.39-0.47) for GWL-1, and it was no matter what cumulative precipitation sums (from 2 to 7 days) were used. While in the case of GWL-7, the highest correlation (0.9) was set with a cumulative precipitation sum of 7 days and days from 1 to 5 showed almost no correlation. The analysis showed that the closest correlation existed for precipitation sums in longer cumulative period (5-7 days). It means that the reaction of GWL to high precipitation amount high-

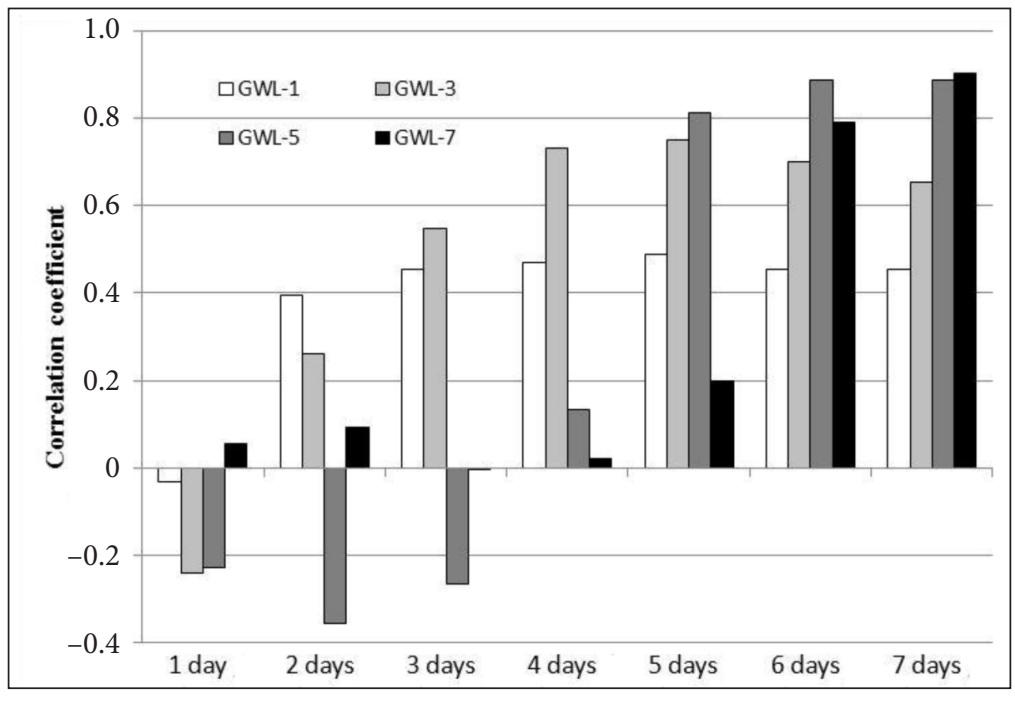

Fig. 11. Values of correlation coefficients between cumulative precipitation sums (from 1 to 7 days) and cumulative GWL change sums for the same days in Rekkyva 
lights throughout a 7-day period, and if precipitation lasts up to 4 days, the relation is weaker, not so strong.

The correlation analysis showed a strong precipitation effect on the GWL change. According to regression coefficients it needs $36 \mathrm{~mm}$ of precipitation for GWL-1 to raise GWL by $1 \mathrm{~cm}$, while the precipitation sum would be more than $55 \mathrm{~mm}$ for GWL-3 to raise GWL by the same value.

The most extreme precipitation event was observed in September 2013 when four days in a row the precipitation amount exceeded $15 \mathrm{~mm}$ per day. Rain started on 16 September 2013 (Fig. 12) - GWL raised $8.7 \mathrm{~cm}$ during the first five days, and $10.5 \mathrm{~cm}$ during eight days. The most intense GWL change was recorded on 18-19 September $(2.8$ and $3.1 \mathrm{~cm} /$ day, respectively), i. e. on the $3 \mathrm{rd}$ and 4 th days of heavy rains. The rain continued throughout next five days with a slight increase and stabilisation of GWL; after that GWL started to decrease. The analysis revealed that the strongest correlation between the cumulative precipitation sums and GWL change was formed on the second day of raining, i. e. correlation coefficients were equal to 0.99 .

The effect of dry periods ( $>10$ days without precipitation) on GWL changes was not significant during the cold period (October-March) because evapotranspiration is almost zero and GWL does not decrease. The analysis of 7 cases (Fig. 13) in the warm period (from April to September) revealed that GWL decrease depended on the duration of the dry period (the longest period without precipitation was 18 days). GWL fell from 2.0 to $7.4 \mathrm{~cm}$ during such events.
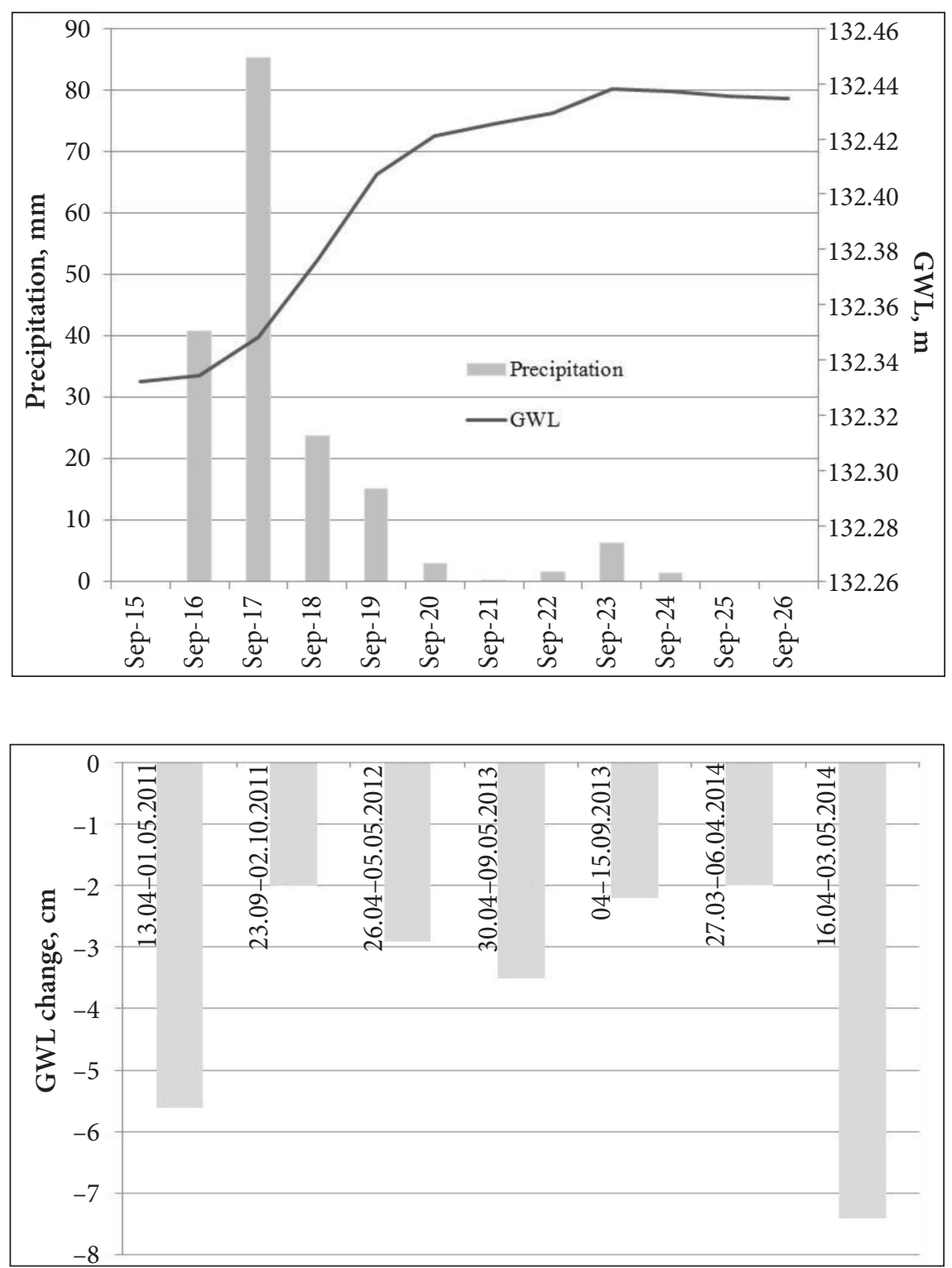

Fig. 12. The precipitation amount and groundwater level on 15-26 September 2013 in the Rèkyva peatbog

Fig. 13. The overall decrease of GWL during periods without precipitation at least 10 consecutive days in Rèkyva in 20112014 


\section{CONCLUSIONS}

1. The groundwater level (GWL) tends to decrease during the warm period in Čepkeliai and Rekyva peatbogs. The largest average decrease was observed in the sand, while the smallest one in the thick layer of peat. GWL is the highest at the end of the cold season (middle of April) because of intensive snow melting processes. The lowest values of GWL are reached in the middle of October.

2. Precipitation is the most important factor determining GWL fluctuations during the warm season as well as determining the annual changes in the peatbogs. Reaction of GWL fluctuations was very much determined by different soil types (sand, thin peat and thick peat layers) in Čepkeliai. In almost all cases the correlation between the annual and warm season precipitation and GWL values was the strongest in the sand, while in the thick layer of peat such relation was weaker. While the relationship between the 10day rainfall anomalies and GWL changes is stronger in the thick layer of peat (correlation coefficient is 0.71 compared to 0.59 for sand).

3. The highest, statistically significant relationships were found between the GWL fluctuations and the hydrothermal coefficient (HTC), while the correlation of GWL changes with the potential evapotranspiration (PET), air temperature and precipitation amount were weaker or even statistically insignificant in Čepkeliai and Rèkyva peatbogs. It means that a complex of hydrothermal conditions could be used for the identification of warm season GWL fluctuations along with the precipitation amount.

4. The GWL fluctuations in the Rèkyva peatbog depends on the distance from Rèkyva Lake, absolute altitudes, thickness of the peat layer, and from the season of the year. In the cold season more distant boreholes had higher maximum and lower minimum GWLs than the ones closest to the lake. An opposite effect was found in the warm season: lower maximum and higher minimum GWLs were determined for distant boreholes than for the ones closest to the lake.

5. The effect of lasting rains on GWL increase was evaluated in the Rekyva peatbog. The closest correlation existed for precipitation sums in a longer cumulative period (5-7 days). It means that the reactions of GWL to high precipitation amount show up throughout a week, and if the precipitation period is shorter than 4 days, the relation is not so strong. According to the September 2013 precipitation case the strongest correlation between the cumulative precipitation sums and GWL change was formed on the second day of raining.

\section{ACKNOWLEDGEMENTS}

This study has been funded by the LithuanianSwiss cooperation program to reduce economic and social disparities within the enlarged European Union under the name CLIMPEAT (Climate Change in Peatlands: Holocene Record, Recent Trends and Related Impacts on Biodiversity and Sequestered Carbon), Project Agreement No. CH3-ŠMM-01/05.

Received 25 September 2015 Accepted 23 October 2015

\section{REFERENCES}

1. Auterives C., Aquilina L., Bour O., Davranche M., Paquereau V. 2011. Contribution of climatic and anthropogenic effects to the hydric deficit of peatlands. Hydrological Processes. 25: 2890-2906, doi: 10.1002/hyp.8052.

2. BACC Author Team. 2008. Assessment of Climate Change for the Baltic Sea Basin. Regional Climate Studies. Springer-Verlag Berlin-Heidelberg.

3. BACC II Author Team. 2015. Second Assessment of Climate Change for the Baltic Sea Basin. Regional Climate Studies. Springer International Publishing.

4. Edvardsson J., Rimkus E., Corona C., Šimanauskiené R., Kažys J., Stoffel M. 2015a. Exploring the impact of regional climate and local hydrology on Pinus sylvestris L. growth variability - A comparison between pine populations growing on peat soils and mineral soils in Lithuania. Plant and Soil. 392: 345-356, doi: 10.1007/s11104-015-2466-9.

5. Edvardsson J., Šimanauskienè R., Taminskas J., Baužienè I., Stoffel M. 2015b. Increased tree establishment in Lithuanian peat bogs - Insights from field and remotely sensed approaches. Science of the Total Environment. 505: 113-120.

6. Frolking S., Roulet N., Lawrence D. 2009. Issues related to incorporating northern peatlands into global climate models. In: A. J. Baird, L. R. Belyea, X. Comas, A. S. Reeve, L. D. Slater (eds.). Carbon Cycling in Northern Peatlands. Geophysical Monograph Series. 19-35. 
7. Gaigalas A., Vaikutienè G., Vainorius J., Kazlauskas M. 2008. Development of Lake Rèkyva and its environment in Late Pleistocene and Holocene. Geologija. 1: 28-36.

8. Jarašius L., Matulevičiūtè D., Pakalnis R., Sendžikaitè J., Lygis V. 2014. Drainage impact on plant cover and hydrology of Aukštumala raised bog (western Lithuania). Botanica Lithuanica. 20(2): 109-120.

9. Kettridge N., Waddington J. M. 2014. Towards quantifying the negative feedback regulation of peatland evaporation to drought. Hydrological Processes. 28: 3728-3740, doi: 10.1002/hyp.9898.

10. Kibirkštis G. 2002. Distribution of Čepkeliai Moor Waterflow. Geografija. 38(2): 14-17.

11. Kibirkštis G. 2007. Pelkès hidrologinio monotoringo 2007 m. ataskaita. Čepkelių valstybinio gamtinio rezervato direkcija.

12. Kirpotin S. N., Berezin A., Bazanov V., Polishchuk Y., Vorobiov S., Mironycheva-Tokoreva N., Kosykh N., Volkova I., Dupre B., Pokrovsky O., Kouraev A., Zakharova E., Shirokova L., Mognard N., Biancamaria S., Viers J., Kolmakova M. 2009. Western Siberia wetlands as indicator and regulator of climate change on the global scale. International Journal of Environmental Studies. 66(4): 409-421.

13. Linkevičienė R., Taminskas J., Mažeikis A. 2008. Simple method of modelling of bog lake's water level fluctuation: case study of Rèkyva lake. Anthropogenic and Natural Transformations of Lakes. 2: 95-98.

14. MacDonald G. M., Beilman D. W., Kremenetski K. V., Sheng Y., Smith L. C., Velichko A. A. 2006. Rapid early development of circumarctic peatlands and atmospheric $\mathrm{CH}_{4}$ and $\mathrm{CO}_{2}$ variations. Science. 314(5797): 285-288, doi: 10.1126/science.1131722.

15. Mažeika J., Guobytė R., Kibirkštis G., Petrošius R., Skuratovič Ž., Taminskas J. 2009. The use of carbon-14 and tritium for peat and water dynamics characterizations: case of Čepkeliai peatland, Southeastern Lithuania. Geochronometria. 34: 41-48.

16. Mierauskas P., Pranaitis A., Sinkevičius S., Taminskas J. 2005. Pelkiu ekosistemos: raida, ịvairové, reikšmé, apsauga. Vilnius: Lietuvos gamtos fondas.

17. Mitsch W. J., Hernandez M. E. 2013. Landscape and climate change threats to wetlands of North and Central America. Aquatic Sciences. 75: 133149, doi: 10.1007/s00027-012-0262-7.
18. Pakalnis R., Sendžikaitė J., Avižienè D. 2008. Experimental preparation of raised bog rehabilitation in the process of peat-cutting. Proceedings of the Conference "Peat in Horticulture and the Rehabilitation of Peatlands after Peat Extraction: Which Issues for Tomorrow". Lamoura, French Jura, France. 121-129.

19. Povilaitis A., Taminskas J., Gulbinas Z., Linkevičienè R., Pileckas M. 2011. Lithuanian Wetlands and Their Water Protective Importance. United Nations Development Programme and Global Environmental Facility Project No LIT/03/G31 "Conservation of Inland Wetland Biodiversity in Lithuania”. Vilnius: Nature Heritage Fund.

20. Ruseckas J., Grigaliūnas V. 2008. Effect of drainblocking and meteorological factors on groundwater table fluctuations in Kamanos mire. Journal of Environmental Engineering and Landscape Management. 16(4): 168-177.

21. Selianinov G. T. 1928. On agricultural climate valuation. Agricultural Meteorology. 20: 165-177.

22. Šimanauskienė R., Taminskas J., Linkevičienè R. 2008. Anthropogenic and climate change influence towards the wetland ecosystem (the case study of Rèkyva wetland). In: D. Cygas, K. D. Froehner (eds.). Selected Papers of the 7th International Conference in Environmental Engineering. Vilnius, Lithuania: Vilnius Gediminas Technical University. 394-400.

23. Taminskas J., Linkevičienè R., Mažeika J., Kibirkštis G. 2008. The impact of global climate change for hydrometeorological conditions of Čepkeliai peatland: the elements of vertical water cycle. Annales de Geophysicae. 40: 50-60.

24. Taminskas J., Linkevičienè R., Skuodienè N., Dilys K., Šmatas V. 2015. Rékyvos durpiu telkinio monitoringo ataskaita. 2014 metai. Vilnius: Gamtos tyrimų centras.

25. Taminskas J., Pileckas M., Šimanauskienė R., Linkevičienè R. 2012. Wetland classification and inventory in Lithuania. Baltica. 25: 33-44.

26. Thornthwaite C. W., Mather J. R. 1957. Instructions and Tables for Computing Potential Evapotranspiration and the Water Balance. Centerton, N. J.: Laboratory of Climatology, Drexel Institute of Technology. 
Justas Kažys, Egidijus Rimkus, Julius Taminskas, Sigita Butkutè

\section{HIDROTERMINIŲ SĄLYGŲ POVEIKIS GRUNTINIO VANDENS LYGIO POKYČIAMS: ČEPKELIŲ IR RĖKYVOS PELKIŲ (LIETUVA) TYRIMAS}

Santrauka

Aukštapelkès yra natūraliai susiformavusios gamtinès ekosistemos, pasižyminčios unikalia bioivairove ir dalyvaujančios vandens apykaitos ir klimatiniuose procesuose. Straipsnyje nagrinėjami Lietuvos ir Šveicarijos bendradarbiavimo programos projekto „Klimato kaita durpynuose: Holoceno ženklai ir dabartinès tendencijos; ittaka bioịvairovei ir anglies deponavimui durpèse (CLIMPEAT)“ metu gauti rezultatai. Tyrimo objektas - gruntinio vandens lygio (GVL) kaita Čepkelių ir Rèkyvos pelkèse. Pagrindinis tyrimo tikslas - įvertinti kritulių poveikį GVL pokyčiams skirtingu laiku ir nustatyti GVL netolygumo priežastis atskiruose gręžiniuose.

Tyrimui panaudoti Čepkelių ir Rèkyvos pelkių GVL monitoringo taškų duomenys (1 lentelè) bei artimiausių joms Varènos ir Šiaulių meteorologijos stočių (MS) temperatūros ir kritulių duomenys. Čepkelių pelkès tyrime remtasi 10 GVL gręžinių, esančių smèlyje, ploname ir storame durpių sluoksniuose, duomenimis (1 pav.), o Rèkyvoje - 6 durpių sluoksnyje įrengtų automatinių GVL matuoklių duomenimis (2 pav.)

Tyrimas paremtas įvairių kritulių rodiklių (metiniu, sezoniniu kritulių kiekiu, 10 dienų kritulių kiekio anomalija), Selianinovo hidroterminio koeficiento (HTK), potencialios evapotranspiracijos (PET) ir GVL pokyčiu ryšiais. Papildomai Rèkyvos pelkèje apskaičiuoti mènesio vidutiniai, maksimalūs, minimalūs GVL ir jų amplitudès skirtingu atstumu nuo ežero esančiuose monitoringo taškuose ( 2 pav.). Ivertintas gausių kritulių (viršijančių $2 \sigma$ standartini nuokrypi ) ir ilgai trunkančių sausų laikotarpių (10 ir daugiau dienų be kritulių) poveikis GVL.

Nustatyta, kad šiltuoju metų laikotarpiu GVL žemèja abiejose pelkèse (3 pav.). Čepkelių pelkèje GVL didžiausi pokyčiai būdingi smèlyje esančiuose gręžiniuose $(27 \mathrm{~cm})$, mažiausi - storame durpių sluoksnyje $(8 \mathrm{~cm})$. Rèkyvos pelkèje vidutinis GVL sumažèjimas per sezoną siekè $10 \mathrm{~cm}$.

Stiprūs statistiškai patikimi koreliaciniai ryšiai $(\alpha=0,05)$ tarp metinių (4a pav.) ir šiltojo sezono (4b pav.) kritulių kiekio bei GVL pokyčio reikšmių nustatyti Čepkelių pelkèje smèlyje ir ploname durpių sluoksnyje įrengtuose gręžiniuose. Storame durpių sluoksnyje koreliacija buvo silpnesnè. Rèkyvos pelkèje dèl trumpo (4 metų) matavimų laikotarpio statistiškai patikimų ryšių nustaty- ti nepavyko, tačiau per 2011-2014 m. Rèkyvoje išryškèjo bendra GVL žemejjimo tendencija (5 pav.).

Vertinant 10 dienų kritulių kiekio anomalijas ir GVL pokyčius Čepkelių pelkèje paaiškèjo, kad storas durpių sluoksnis pasižymèjo stipriausiais ryšiais (koreliacijos koeficiento reikšmè 0,71 , kai smèlyje - 0,59). Tai rodo, kad GVL durpių sluoksnyje yra jautresnis trumpalaikèms kritulių kiekio anomalijoms (6a-c pav.). Rèkyvos pelkeje taip pat gauti aukšti koreliacijos koeficientai $(0,69)$ analizuojant tuos pačius rodiklius (6d pav.).

Čepkelių pelkès GVL pokyčių ryšiai su PET ir HTK rodikliais yra statistiškai patikimi $(\alpha=0,05)$. Teigiama GVL ir PET koreliacija būdinga šaltajam metų laikui - šiltos žiemos pasižymi didesniu kritulių kiekiu. Vasaros metu GVL ir PET ryšiai nèra pastovūs. Taip pat šiltuoju metų laiku visą laiką kinta ryšiai tarp GVL ir HTK reikšmių (7a pav.). Didžiausios koreliacijos koeficiento reikšmès $(0,72)$ pasiekiamos smèlyje esančiuose GVL matavimo gręžiniuose. Rèkyvos pelkèje nepavyko nustatyti patikimų ryšių tarp GVL pokyčių ir PET, tačiau aukšti koreliacijos koeficientai būdingi HTK ir GVL pokyčiams (7b pav.).

Nustatyta, kad Rėkyvos pelkèje aukščiausi GVL fiksuojami balandị, o žemiausi - spalio mènesí (8a pav.). Didžiausios GVL amplitudès būdingos liepos mènesiui (8b pav.). Reakcija i GVL svyravimus Rèkyvos ežere ir atskiruose GVL matavimo gręžiniuose ( 9 pav.) skiriasi priklausomai nuo atstumo iki ežero, absoliutinio aukščio, durpių sluoksnio storio ir metų laiko. Šaltuoju metų laiku labiau nutolę nuo ežero gręžiniai pasižymi aukštesnėmis maksimaliomis ir žemesnèmis minimaliomis GVL reikšmėmis (10a, b pav.). Priešingai yra šiltuoju metų laiku - labiausiai nutolusiems nuo ežero monitoringo taškams būdingos žemesnès maksimalios ir aukštesnès minimalios GVL reikšmès (10a, b pav.). Pagrindinè šių skirtumų priežastis yra ta, kad storas durpių sluoksnis (toliausiai nuo ežero esantys gręžiniai) pasižymi geresnèmis vandens reguliacinèmis savybèmis.

Rèkyvoje ištyrus trumpalaiki gausių kritulių kiekio poveiki GVL nustatyta, kad stipriausi ryšiai tarp suminio kritulių kiekio ir GVL egzistuoja, kai lietus trunka 5-7 dienas, jeigu krituliai krinta iki 4 dienų, ryšys yra silpnesnis (11 pav.). 2013 rugsèjo $16 \mathrm{~d}$. prasidejęs lietus GVL per pirmąsias penkias dienas pakèlè $8,7 \mathrm{~cm}$, o per aštuonias paras - 10,5 cm (12 pav.). Priešingai, ilgai besitęsiantys (10 ir daugiau dienų) laikotarpiai be kritulių žemina GVL (13 pav.).

Raktažodžiai: gruntinio vandens lygis, Lietuvos aukštapelkès, Čepkeliai, Rèkyva, krituliai, CLIMPEAT projektas 